\title{
The Role of Schools to Improve Entrepreneur Spirit in Kumbe Village, Papua
}

\author{
$1^{\text {st }}$ Dewi Putri Anjar Wulan* \\ Department of Management \\ Universitas Musamus \\ Merauke, Indonesia \\ wulan_feb@unmus.ac.id
}

\author{
$2^{\text {st }}$ Nurwijayanti \\ Department of Management \\ Universitas Musamus \\ Merauke, Indonesia \\ nurwijayanti_feb@unmus.ac.id
}

\author{
$3^{\text {st }}$ Aldisa Arifudin \\ Department of Management \\ Universitas Musamus \\ Merauke, Indonesia \\ arifudin_feb@unmus.ac.id
}

\begin{abstract}
The purpose of this article is to find out the role of schools in improving the entrepreneurial spirit of the Kampung Kumbe community. While entrepreneurship itself is one of the supporters that determines the economic ups and downs in an area and even the State. This study uses qualitative methods that are presented descriptively and carried out in Kampung Kumbe, Malind District, Merauke Regency, Papua Province, precisely at SMP Negeri 1 Kumbe. Data collection methods used in this study include observation, interviews, and documentation. The results of this study indicate that the role of schools in enhancing the entrepreneurial spirit of the Marind community in Kampung Kumbe is shown by activities in the school to gain knowledge and skills, help students in forming character traits, and be able to interact with their environment that is balanced through learning that involves participants students must be active and encourage students to recognize and accept entrepreneurial values in developing the ability of students to carry out daily activities.
\end{abstract}

\section{Keywords: the role of schools, entrepreneurship}

\section{INTRODUCTION}

The profession as an entrepreneur so far has not been so attractive for the younger generation. The teens when asked what their goals were, most answered that they wanted to be engineers or doctors. It's very rare for a child or teenager to dream of becoming an entrepreneur from the start. This condition is due to the entrepreneurial or business world, which is still far from the lives of children or adolescents. They do not know or do not know the beauty of the entrepreneurial scene, because so far the environment is less conducive [1].

Entrepreneurship is an attitude, soul, and ability to create something new that is very valuable and useful for himself and others. In its development, the inculcation of entrepreneurial values is not only among entrepreneurs and entrepreneurs but has developed into the world of education, wherein its activities also an entrepreneurial spirit is needed. Entrepreneurship in education aims to form a whole human being, as a person who has the character, understanding, and skills as an entrepreneur [2].

The entrepreneurial spirit that arises in students, such as self-confidence, task, and outcome-oriented, risk-taking, leadership, originality, and future-oriented [3]. Fostering entrepreneurial mentality is one solution and must receive attention. The government, in this case, is responsible for fostering the entrepreneurial spirit of students through entrepreneurship education. Because entrepreneurship education is believed to be an alternative way to reduce the unemployment rate. So entrepreneurship needs to be given to someone in a good education system and is expected to have great potential to become an entrepreneur [4].

Educational institutions not only in charge spawned many graduates, but the important thing is how much the graduates can contribute to society and be able to face the challenges in society. Therefore, schools must be able to improve graduate skills whose purpose is to prepare students to enter the workforce and develop professional attitudes, prepare students to be able to choose a career, be able to compete and be able to develop themselves, prepare graduates to become productive, adaptive and creative citizens, then an educational institution has responsibilities that are very relevant to the formation of an entrepreneurial spirit for its graduates. Entrepreneurship education has been considered as one of the important factors to foster and develop the spirit, soul and entrepreneurial behavior among young people, especially students [5].

SMP Negeri 1 Kumbe is the only first high school in Kumbe village. We took the place of research in 1 Kumbe public junior high school because junior high school was education at the secondary level to continue whether to go to vocational or high school, and this junior high school became the decision-making point for choosing whether to be an entrepreneur or an employee in a company or government. Because if entrepreneurship education is given when it is in high school or vocational school it can be said to be a bit late. We recommend that entrepreneurship education starts early.

The younger generation is expected to have entrepreneurial behavior to bridge them so that they do not become unemployed in the future [6]. Today's SMK students, even though they have attended vocational schools, many graduates prefer to be employees or create jobs. There are even some young Papuans who choose to drop out of school and become unemployed. This is certainly very unfortunate because the native Papuan people who should be the spearhead of Papua are increasingly left behind. If explored deeper, this Papuan young generation should be able to compete with the outside world and advance their regions. Therefore, a study was taken at the first high school. 
Schools have two roles, the role of schools as educational institutions and the role of schools in society. Role of School For Education Institute has a role to develop the human potential that children have to be able to perform the duties of life as a human being, both individually and as members of society by shaping the personality of the children to become an adult who can stand alone in culture and the surrounding community. Role of Schools in Society's role is to prepare children - children to be able to enter the public at a later date. The role of schools as social institutions must be able to carry on values in the life of society, nation and state to help shape the mental attitudes and personalities that are aspired to. Such as making children become selfless citizens in social life, being citizens who are responsible for creating public welfare, both material and spiritual, and forming citizens who have a mental attitude of self-sacrifice by releasing personal interests for the benefit of society, nation, and state.

Through education that takes place in schools, it is hoped that a generation that has a strong character will be able to compete in the era of globalization [7]. Regarding our main problem, namely the role of schools in improving the spirit of entrepreneurship, we must first understand what entrepreneurship is. Until now the concept of entrepreneurship is still developing. Entrepreneurship is an attitude, soul, and ability to create something new that is very valuable and useful for himself and others. Entrepreneurship is a mental attitude and spirit that is always active or creative, creative, creative and unpretentious and strives to increase income in its business activities [1].

There are six characteristics of entrepreneurship, namely: self-confidence, task-oriented and results, risk-taking, leadership, originality, future-oriented [4]. Planting entrepreneurial values can also be done by school management by arranging an entrepreneurial-minded school atmosphere [8]. A higher position at the level of formal education, so real contributions are needed in shaping students' attitudes and entrepreneurial behavior [9].

\section{RESEARCH METHODS}

This type of research is qualitative descriptive where qualitative research methods are research methods based on social reality as something that is complex, dynamic, full of meaning, and the relationship of symptoms is interactive [10]. While the method of writing scientific papers uses a combined writing method that combines the method of writing a literature study and the method of writing the results of observation. Sources of data used in this study are primary data and secondary data. According to Sugiyono in Dewi [11], primary data is data obtained directly in the field by people who are doing research or those who need it. Whereas secondary data is data obtained based on available sources, such as books, previous reports relating to the issues discussed. Some of the main types of references used are books, scientific journals, print editions and online / internet editions and observation of target areas. While the location of observation and data collection took place at SMP Negeri 1 Kumbe, Malind District, Papua Province.

Based on the type of research used are a qualitative descriptive method, the data collection techniques in qualitative research through interviews, observations, and documentation because the data generated in the form of non-numeric data so that researchers conduct interviews directly to the speakers. To collect data needed in this study, researchers used data collection techniques including (1) library research, (2) field research, research conducting research directly in the field to obtain data or conduct information directly from respondents using several observation techniques and interviews [10].

Data analysis used in this study is a qualitative analysis using an interactive analysis model. Miles and Collaboration in Sugiyono [10], argued that in qualitative research, data analysis begins before entering the field, during being in the field and after the field. But the practice of qualitative data analysis runs during the data collection process from the start of the study to completion. The stages of data analysis are as follows: (1) Reduction Data, (2) Display Data, (3) Conclusion / Verification

\section{RESULTS AND DISCUSSION}

The values of entrepreneurship contain characters in both the child's life. This is in line with the opinion of Wibowo in Adevia [8] that entrepreneurship education should be done from an early age. Of course, the material presented is adjusted to the educational field and age of students. This entrepreneurship spirit contributes positively to the lives of children. Entrepreneurship aims to make someone better and not merely make a person rich. Entrepreneurship is about collaboration with others because entrepreneurship also talks about how to provide benefits for others. Through this entrepreneurship education, it is hoped that in the future children can be independent and provide work opportunities for others.

The survey results explain that there are still many students who are less interested in entrepreneurial learning because there are still those who have the mindset as job seekers not as job creators. This is due to the lack of selfconfidence of students about understanding entrepreneurship, and the inculcation of entrepreneurial motivation early on both at home or at school which is the reason they are reluctant to entrepreneurship.

The results of interviews conducted with some students of SMP Negeri 1 Kumbe, said that they have the aspiration to become an entrepreneur. This proves that the role of schools in improving the entrepreneurial spirit for their students has gone well.

The world of education, especially schools more specifically teachers, has a great moral responsibility for the future of students. If they are good, this nation is good too. However, if they are destroyed, this nation is also destroyed. Because of the importance of students for this future, one thing that must be possessed is that everyone must have skills as a branding self or self-image.

The results of direct interviews conducted with teachers in SMP Negeri 1 Kumbe, said that they had tried to teach about entrepreneurship, but due to limited facilities and infrastructure for learning that caused the things that teachers delivered to students were not well delivered and were not understood by their students. However, not all students are like that, only some students do not understand the entrepreneurial spirit. Most of the students in SMP Negeri 1 Kumbe already have a pretty good entrepreneurial spirit, this is evidenced by the existence of some of the students' work being marketed. 
Entrepreneurial skills which were held at the school is practical entrepreneurial training in the process of education and learning. Children are conditioned to carry out entrepreneurial activities even though for this condition schools, teachers, and students must equate perceptions, and steps in carrying out activities. Long before, in the process of inculcating an entrepreneurial spirit through education, there was a process of forming an entrepreneurial soul through learning and self-habituation as the originator of character in the future. Explicitly, at the junior high school level, there is no obligation to study entrepreneurship. However, if it is related to the needs, hopes and support of the government towards the growth of the entrepreneurial spirit through education, then this needs to get more attention.

Schools as educational institutions should not only focus on developing children's intellectual intelligence, but also focus on developing the character or personality of children by national education goals. School is one of the socialization institutions that play a role in shaping knowledge, attitudes, values, norms, essential behaviors, and hopes to be able to participate effectively in society.

The role of the teachers, they must be more active in growing students' entrepreneurial spirit in success by providing the motivation and strong support needed by students [12]. For government efforts to be carried out well in fostering an entrepreneurial spirit among students, it is necessary to have many educators who are also entrepreneurial in spirit. The obstacle is that there are still a lot of educators who are not yet entrepreneurial so that entrepreneurship is finally conveyed only to the knowledge (theory). There are still many teachers who do not utilize the learning media facilities, whereas the use of learning media can have a positive effect on students to stimulate soft skills that are useful for forming an entrepreneurial spirit such as for critical and creative thinking.

In enhancing the spirit of entrepreneurship and increasing entrepreneurship, the government has issued Presidential Instruction No. 4 of 1995 concerning the National Movement to Promote and Cultivate Entrepreneurship. This instruction mandates all Indonesians and people to develop entrepreneurship programs. Furthermore, in supporting the 2015-2019 Creative Economy Development, namely the development of economic activities based on the creativity, skills, and talents of individuals to create creative and creative power of individuals who are economically valuable and affect the welfare of the Indonesian people. suggest for teachers to use the direct teaching model in entrepreneurial learning because it is in line with national education goals [13].

\section{CONCLUSION}

The commitment and synergy of school management by implementing appropriate strategies can accelerate the process of fostering an entrepreneurial spirit through education in the school environment. Implementation of these strategies is not only targeted at junior high school students, but also teachers as educators. The synergy of parents, teachers, and school conditioning in such a way both from facilities and policies is no less important and must be aligned with the expected ultimate goal of the emergence of student graduates with the entrepreneurial spirit.

\section{ACKNOWLEDGMENT}

Our utmost appreciation accompanied thanks to the headmaster of Kumbe Junior high school Negeri 1 and all teachers, staff, and students for their assistance in this research. And thanks to Musamus University especially the Rector who always supports us. May God bless the duties and work of all you.

\section{REFERENCES}

[1] Safroni Isrososiawan, "Peran Kewirausahaan dalam Pendidikan," Apl. Kecerdasan Emosional Dalam Perilaku Organ., vol. IX, 2014.

[2] A. F. Teuku Syahril Daoed, M. Amri Nasution, "Pengembangan Peran Sekolahdan Kepercayaan Diri Siswa dalam Meningkatkan Karakter Kewirausahaan Berbasis Kurikulum 2013 pada Siswa/i SMKS TIK Darussalam Medan," RESWARA J. Pengabdi. Kpd. Masy., vol. 1, pp. 56-64, 2020.

[3] M. R. Irwansyah and L. E. Tripalupi, "Menguji Pengaruh Pendidikan Kewirausahaan dalam Pembentukan Jiwa Wirausaha di Kalangan Mahasiswa," Int. J. Soc. Sci. Bus., vol. 2, no. 4, p. 251, 2018, doi: 10.23887/ijssb.v2i4.16340.

[4] W. R. Wahyuni and W. Hidayati, "Peran Sekolah dalam Membentuk Keterampilan Wirausaha Berbasis Tauhid di SD Entrepreneur Muslim Alif-A Piyungan Bantul Yogyakarta," Manag. J. Manaj. Pendidik. Islam, vol. 2, no. 2, pp. 359-377, 2017, doi: 10.14421/manageria.2017.22-08.

[5] S. Khadijah and M. Fraick Nicky Gillian Ratumbuysang, "Midwifery Enterpreneurship Education Influences On Entrepreneurial Motivation Of Students At Sari Mulia Midwifery Academy Banjarmasin," Atl. Press, vol. 6, no. Smichs, pp. 456462, 2017, doi: 10.2991/smichs-17.2017.57.

[6] S. Ms. and H. Tantri Hardini, "Personality, Learning Entrepreneurship, and Attitude as Predictors of Economic Studentsr Entrepreneur Behavior," Atl. Press, vol. 222, no. SoSHEC, pp. 320-324, 2018, doi: 10.2991/soshec-18.2018.69.

[7] S. Suryaman and H. Karyono, "Leading Entrepreneurship Education-Based Primary Schools," Atl. Press, vol. 128, no. Icet, pp. 135-139, 2017, doi: 10.2991/icet-17.2017.22.

[8] A. I. Kusuma, "Strategi Manajemen Sekolah Dasar Dalam Menumbuhkan Jiwa Kewirausahaan,” J. JPSD (Jurnal Pendidik. Sekol. Dasar), vol. 4, no. 1, p. 77, 2017, doi: 10.26555/jpsd.v4i1.a9590.

[9] N. Ratmaningsih, "The Effect of Campus Environment towards Students' Entrepreneurship Attitude and Behavior," Atl. Press, vol. 15, pp. 770-778, 2016, doi: 10.2991/gcbme-16.2016.144.

[10] Sugiyono, Metode Penelitian Kuantitatif, Kualitatif, Dan R\&D. bandung: Alfabeta, 2015.

[11] D. Wulan, A. Arifudin, and Nurwijayanti, "Improvement Of Employee Performance PT PLN (Persero) Area Merauke Reviewed From Work Discipline Of Employees," Atl. Press, vol. 363, no. Icss, pp. 73-77, 2019, doi: 10.2991/icss-19.2019.198.

[12] S. Musrifah, "Entrepreneurship Learning Model in Improving Student's Spiritual Intelligence," Atl. Press, vol. 125, no. Icigr 2017, pp. 219-222, 2018.

[13] L. Zahara, A. Ananda, G. Ganefri, and R. Ridwan, "Development of Direct Instruction Learning Model on Entrepreneurship Subject at State Vocational High School (VHS) of Farming Development Padang," Atl. Press, vol. 116, no. Icovet, pp. 206208, 2017, doi: 10.2991/icovet-17.2017.44. 